Marquette University

e-Publications@Marquette

College of Education Faculty Research and

Publications

Education, College of

$2-1-2002$

\title{
Hierarchical Factor Analysis of the Quick Discrimination Index
}

\author{
Alan W. Burkard \\ Marquette University, alan.burkard@marquette.edu \\ James Jones \\ Ball State University \\ Michael Johll \\ Baldwin-Wallace College
}

Post-print. Educational and Psychological Measurement, Volume 62, No. 1 (February 2002), DOI. (C) 2002 SAGE Publications. Used with permission. 


\title{
Hierarchical Factor Analysis of the Quick Discrimination Index
}

\author{
Alan W. Burkard \\ Counselor Education and Counseling Psychology \\ Marquette University \\ Milwaukee, WI \\ James A. Jones \\ Ball State University \\ Muncie, IN \\ Michael P. Johll \\ Baldwin Wallace College \\ Berea, $\mathrm{OH}$
}

\begin{abstract}
Prior factor analytic studies of the Quick Discrimination Index (QDI) have used principal components factor analysis to develop and validate a three-factor structure with a racially heterogeneous sample. In this investigation, Study 1 explored the factor structure of the QDI with a sample of 428 White university students using a hierarchical factor analysis. The analysis showed that a structure with four first-order factors and one secondorder factor was the best fit for the data. Study 2 tested the original threefactor structure and a higher order factor structure from Study 1 in a confirmatory factor analysis using a sample of 363 White students. The implications for interpretation and future research are discussed.
\end{abstract}

Over the past couple of decades, researchers have recognized that the measurement of prejudice attitudes has become increasingly complex (Biernat \& Crandall, 1999; Burkard, Medler, \& Boticki, 2001). Two movements have contributed to this growing complexity in the 
measurement of prejudice. First, due to changing norms and social mores in this country, overt expressions of racism and prejudice are becoming less acceptable, although negative attitudes and stereotypes toward minority groups continue to persist (Gaertner \& Dovidio, 1986). This change has presented a measurement dilemma in that individuals often respond to self-report measures of explicit prejudice with socially desirable responses rather than the less than socially desirable responses that they may hold (von Hippel, Sekaquaptewa, \& Vargas, 1997). A second movement concerns our increased understanding of the complexity of the structure and expression of prejudice attitudes. Past research on stereotypes and prejudice measurement has been predominately concerned with understanding explicit expressions of prejudice (Greenwald, 1990). Contemporary prejudice researchers are increasingly focusing on the multidimensional nature of attitudes and emerging interest in cognitive processes related to the expression of prejudice. For example, recent research by Dunton and Fazio (1997) indicated that some individuals are motivated to actively control racist behaviors. This suggests that an independent cognitive and/or affective process may mediate the explicit expression of these prejudiced attitudes.

Several recent measures of prejudice have emerged to address these concerns (for reviews, see Biernat \& Crandall, 1999; Burkard et al., 2001). A number of these more contemporary measures of racial prejudice have acknowledged that racist attitudes are changing. As a result, these measures attempt to measure subtler aspects of racist and prejudice attitudes, and they recognize and attempt to measure the multidimensional nature of prejudice (Biernat \& Crandall, 1999; Burkard et al., 2001). One particular instrument, the Quick Discrimination Index (QDI) (Ponterotto et al., 1995), has initially been shown to measure aspects of this more subtle form of prejudice and to measure prejudice from a multidimensional perspective. One of the unique features of this instrument is the intent to use this instrument with a variety of racial/ethnic groups to measure prejudice attitudes. The initial factor and validation studies have supported the use of the QDI for these purposes (Ponterotto et al., 1995) and demonstrated that three factors emerged from a multiracial sample (e.g., cognitive attitudes, affective-interpersonal reactions, attitudes toward women). In a follow-up investigation involving three independent samples, a permission has been granted for this version to appear in e-Publications@Marquette. SAGE Publications does not grant permission for this article to be further copied/distributed or hosted elsewhere without the express permission from SAGE Publications. 
confirmatory factor analysis (CFA) affirmed the factor structure identified in the original investigation (Utsey \& Ponterotto, 1999). Although the QDI appears to have promising psychometric properties, it is important that research continue to examine the generalizability of the tridimensional factor structure (Ponterotto et al., 1995).

The current studies reported in this article were designed to assess the factorial validity of the QDI. The purpose of Study 1 was to examine the temporal stability and generalizability of the QDI factor structure with a sample of White participants. Prior investigations on the QDI have acknowledged that the tridimensional factor structure should be assessed with various racial groups to understand the generalizability of the measurement based on this instrument and the stability of the factor structure (Utsey \& Ponterotto, 1999). In particular, Burkard et al. (2001) suggested that future investigations examine within-group differences of the QDI factor structure with various samples of racial or ethnic groups to continue to develop and understand the psychometric properties of the instrument and to further understand the nature of racial prejudice. Study 1 examined the factor structure of the QDI with a racially homogenous sample of White participants using a hierarchical factor analysis procedure (Schmid \& Leiman, 1957). The QDI factor structure was further examined in Study 2 using CFA with an independent sample of White participants.

\section{Study 1: Hierarchical Factor Analysis}

\section{Method}

\section{Sample}

This study was conducted during the 1998 and 1999 academic year at a university in the Midwest. The sample consisted of 428 volunteer students living in the residence hall system. The ages of the participants ranged from 17 to 22 , with a mean age of 18.92 . Of the participants, $44 \%(n=189)$ were males and $56 \%(n=239)$ were females. 
NOT THE PUBLISHED VERSION; this is the author's final, peer-reviewed manuscript. The published version may be accessed by following the link in the citation at the bottom of the page.

\section{Instrument}

The QDI was developed to measure discrimination attitudes toward women and cognitive and affective prejudice attitudes (Ponterotto et al., 1995). The QDI is a 30-item self-report measure with each item measured by a 5-point Likert-type scale. Ponterotto et al. (1995) reported the internal consistency for the three subscales across two samples as cognitive factor, .80 and .85; affective factor, .83 and .83 ; and women's factor, .76 and .65 .

\section{Procedure}

Participants for the first study were randomly selected from the residence hall system. The instruments were distributed to 600 residents in the fall semester, and student research assistants made one follow-up contact to increase the response rate. All participants used in this study were provided with informed consent and voluntarily agreed to participate. Each survey packet included the informed consent letter, the research instrument, and a demographic questionnaire. A total of 432 surveys were collected for a response rate of $72 \%$. Of the 432 materials returned, 428 were considered usable for this study.

\section{Data Analysis}

Studies on the QDI have consistently found that a three-factor oblique model represents the best fit for the data (Ponterotto, Potere, \& Johansen, 2000). As Gorsuch (1983) noted, "Implicit in all oblique rotations are higher order factors" (p. 255). These findings are consistent with many models of attitude measurement and suggest that a latent general prejudice attitude may account for the moderate relationship found between the three factors of the QDI. To date, research on the QDI factor structure has not attempted to examine the existence of a higher order latent structure of prejudice as measured by the QDI. The examination of second-order factors has been compared to looking at mountains in the distance, whereas looking at first-order factors gives more details of the valleys and peaks (Gorsuch, 1983; Thompson, 1990). This topographical analogy suggests that the hierarchical approach can give multiple perspectives

Educational and Psychological Measurement, Vol. 62, No. 1 (2002): pg. 64-78. DOI. This article is @ SAGE Publications and permission has been granted for this version to appear in e-Publications@Marquette. SAGE Publications does not grant permission for this article to be further copied/distributed or hosted elsewhere without the express permission from SAGE Publications. 
of the data, yielding a broader understanding. Consequently, a hierarchical factor analysis was conducted using the program SECONDOR (Thompson, 1990).

\section{Results}

\section{Hierarchical Factor Analysis}

A hierarchical factor analysis was conducted based on the Schmid and Leiman (1957) approach to examining hierarchical factor models. Solutions with two, three, four, and five primary factors and a single general factor were inspected to identify the most interpretable factor structure. Of the four solutions, the four-factor extraction with a general factor appeared to be the best fit for the data, accounting for $44 \%$ of the total variance. As recommended by Stevens (1996), critical values for correlation coefficients at $p=.01$ (two-tailed test) were doubled, and only structure coefficients exceeding this in absolute value were considered statistically significant. For a sample of 428 participants, the resulting minimum structure coefficient criterion was .25. If a variable cross-loaded, only the largest coefficient was considered salient in the interpretation of the primary factors. Using these criteria, all 30 items were salient on one of the four primary factors, and 24 items were salient on the secondary factor. The four first-order factors accounted for $24 \%$ of the explained variance, the second-order factor or a "G" factor accounted for $20 \%$ of the explained variance; combined, this accounts for $44 \%$ of the total explained variance. The appendix presents the results of the hierarchical factor analysis next to the factor structure matrix reported by Ponterotto et al. (1995). (See Ponterotto et al., 1995, for a complete listing of QDI items.) Structure coefficients below the minimum criteria were blanked to aid identification of the factor structures. The first-order factors partially matched the factor structure identified in the development sample by Ponterotto et al. (1995).

First-order Factor I accounted for $4 \%$ of the total variance and was composed of five items (Items 3, 9, 13, 18, and 19) focusing on political/institutional attitudes toward racial diversity. Each of these items loaded on the Cognitive Attitudes factor identified in the development study by Ponterotto et al. (1995) and labeled as P.I in the appendix. permission has been granted for this version to appear in e-Publications@Marquette. SAGE Publications does not grant permission for this article to be further copied/distributed or hosted elsewhere without the express permission from SAGE Publications. 
First-order Factor II accounted for $6 \%$ of the total variance and was composed of nine items focusing on affective/interpersonal attitudes toward racial diversity. Seven of the items (Items 4, 8, 11, $15,17,24$, and 29) from this first-order Factor II were the same items that were salient for the Affective-Interpersonal Attitude factor identified by Ponterotto et al. (1995) and labeled as P.II in the appendix. Items 27 and 28 were also found to be salient for first-order Factor II. Item 27 was found to be salient for the Cognitive Attitudes factor in the development study, whereas Item 28 was not salient for any factor.

First-order Factor III accounted for $8 \%$ of the total variance and was composed of eight items focusing on attitudes toward women's equity. Five items (Items 1, 7, 16, 20, and 30) were salient for the factor identified as Attitudes Toward Women's Equity by Ponterotto et al. (1995), labeled as P.III in the appendix. Items 2, 23, and 25 also were salient for first-order Factor III in this study; however, only Item 23 was salient for the General Cognitive factor in the original Ponterotto et al. study, whereas Items 2 and 25 were unassigned.

First-order Factor IV accounted for $6 \%$ of the total variance and was composed of eight items. The content of these items focused on general cognitive attitudes toward diversity and multicultural issues. Four of the items (Items 5, 10, 12, and 21) from first-order Factor IV were not salient for any of the three factors originally identified in the Ponterotto et al. (1995) study. Four items (Items 6 and 14 from the Attitudes Toward Women factor and Items 22 and 26 from the General Cognitive factor) that were salient for two factors from the Ponterotto et al. development study represented the remaining items for first-order Factor IV of this study.

\section{Intercorrelations and Internal Consistency}

Using the multiple-group approach to factor scores (Gorsuch, 1983), the results of the means, standard deviations, factor intercorrelations, and coefficient alphas for the four primary factors and the secondary general factor are presented in Table 1 . The firstorder factor intercorrelations range from .24 to .50, which suggests 
that the factors are moderately correlated and not redundant. The intercorrelations between the first-order and second-order factors range from .48 to .79 , which suggests a moderate to strong correlational relationship. The coefficient alphas range from .61 to .86 for each of the first-order and second-order factors.

\section{Study 2: Confirmatory Factor Analysis}

\section{Method}

\section{Sample}

No participants from the first sample were included in the sample for Study 2. The total sample for Study 2 consisted of 363 participants. The ages of the participants ranged from 17 to 23, with the mean age of 19.18 . In terms of gender, $36 \%(n=133)$ were male and $64 \%(n=230)$ were female.

\section{Procedure}

Participants for the second study were randomly selected from the residence hall system. The instruments were distributed to 600 residents in the fall semester, and student assistants made one followup contact to attempt to increase the response rate. All participants used in this study were provided with informed consent and voluntarily agreed to participate. Each survey packet included the informed consent letter, the research instrument, and a demographic questionnaire. A total of 364 surveys were collected for a response rate of $61 \%$. Of the 364 materials returned, 363 were considered usable for this study.

\section{Results}

\section{Intercorrelations and Internal Consistency}

Applying the factor structure identified in Study 1 , the results of the means, standard deviations, factor intercorrelations and coefficient alphas from this second sample of White university students are presented in Table 1 . The first-order factor intercorrelations range 
NOT THE PUBLISHED VERSION; this is the author's final, peer-reviewed manuscript. The published version may be accessed by following the link in the citation at the bottom of the page.

from .27 to .49, which are very consistent with the findings from Study 1 . This would seem to support the notion that the four primary factors are not redundant, but remain consistent with the notion of a latent factor structure with a second-order factor. For each of the factors, the coefficient alphas range from .55 to .84.

\section{Confirmatory Factor Analysis}

A CFA was conducted using the QDI scores from the 363 participants comparing the hierarchical model identified in Study 1 , but it was now represented by higher order and bifactor models as suggested by Yung, Thissen, and McLeod (1999), the three-factor oblique model identified in the Ponterotto et al. (1995) development study, and the null model. The latent structure of the higher order factor and bifactor models are similar except that the effects of the $G$ factor on the observed variables are mediated by the four primary factors in the higher order factor model; however, in the bifactor model, both $\mathrm{G}$ and the primary factors have direct effects on the observed variables. The higher order model is nested within the bifactor model because the bifactor model is less restrictive by not constraining the direct effects of $\mathrm{G}$ on the observed variables to zero, as is done implicitly in the higher order factor model. Yung et al. (1999) also demonstrated that higher order factor models without direct effects on observed variables from the higher order factors are nested within general hierarchical factor models. The bifactor model is considered a special case of the general hierarchical factor model in which the direct effects of $G$ on the primary factors are set to zero (Yung et al., 1999).

Several fit indices were examined to assess the relative goodness of fit. Chi-square statistics were used to compare the models; however, the chi-square statistic is typically limited in large samples sizes (Bentler \& Bonett, 1980). Consequently, the goodness of fit was examined by the relative chi-square $\left(\chi^{2} / d f\right)$; Carmines \& McIver, 1981), normed fit index (NFI) (Bentler \& Bonett, 1980), nonnormed fit index (NNFI) or Tucker-Lewis coefficient (Bollen, 1989), parsimony adjustment to the NFI (PNFI) (James, Mulaik, \& Brett, 1982), and the root mean square error of approximation (RMSEA) (Browne \& Cudeck, 1993). Table 2 summarizes the goodness-of-fit 
indices from the CFA. The three-factor oblique is based on 23 observed variables, whereas the higher order factor and bifactor models have all 30 variables observed. Thus, the improvement in chi-square cannot be directly compared across the 23 and 30 observed variables models. An examination of the goodness-of-fit indices in Table 2 does indicate that the oblique three-factor, higher order four primary factor, and the bifactor models all yielded similar goodness-of-fit indices. The higher order and bifactor models, however, have the advantage of accounting for all 30 items of the QDI, unlike the 23-item solution in the development study (Ponterotto et al., 1995). Figures 1, 2, and 3 provide a graphic comparison of these three models. The null models had a chi-square to $d f$ ratio of greater than 3 to 1 , which is indicative of an unacceptable fit (Carmines \& McIver, 1981). For all models except the null, values for the NFI and NNFI were in the .96 to .98 range, suggesting that each model was fitting the data reasonably well (Bentler \& Bonett, 1980) and values for RMSEA were .07 or less, also indicative of a reasonable fit (Browne \& Cudeck, 1993). The PNFI values for all models except the null ranged from .79 to .83 , which would indicate that for all three models, fit is being achieved at some sacrifice to parsimony. The improvement in the chi-square between the higher order factor and bifactor models $\left(\chi^{2}=45.04, d f=19, p<\right.$ $.001)$ suggests that a superordination conception is too restrictive and the two-layer hierarchical factor model is a better representation for the data. Compared to the higher order factor model, the bifactor model has more breadth, with the $\mathrm{G}$ factor directly affecting the observed variables in the same domain as the primary factors (Yung et al., 1999).

\section{Discussion}

The results of the hierarchical factor analysis and CFA procedures have some important implications for the factor structure and psychometric properties of the QDI and future research. The results of Study 1 and 2 indicate that four first-order factors have emerged from the analyses, as well as a second-order G factor. Three of the factors identified in Study 1 are comparable to the factors originally identified in the development and validation studies by Ponterotto et al. (1995) and in a subsequent validation study (Utsey \& 
Ponterotto, 1999). Unlike prior factor analyses, the newer four-factor structure identified in the hierarchical factor analysis utilizes all 30 items from the QDI. The fourth factor identified in this study emerged from a combination of items that were salient for the cognitive and women's equity scales and items that were not salient for any factor in the tridimensional structure originally identified by Ponterotto et al (1995). The content of this factor appears to focus on general cognitive attitudes toward diversity and multicultural issues. Sample items include "I think that White people's racism toward racial minority groups still constitutes a major problem in America" and "I think the school system, from elementary school through college, should promote values representative of diverse cultures."

An important implication of these findings is that the factor structure of the QDI may not be generalizable across racial ethnic groups. The initial results from this investigation suggest that the factor structure of the QDI with Whites may be different than the ethnically/racially diverse samples from prior investigations. It is important to note that in the QDI development study by Ponterotto et al. (1995), it can be presumed that prejudice attitudes were treated as a universal construct that may have applicability across various ethnic/racial groups (Burkard et al., 2001). Given the difference in the factor structure identified in Studies 1 and 2 with a homogeneous sample of Whites, it would seem plausible that the structure of prejudice may vary across ethnic/racial groups. Utsey and Ponterotto (1999) suggested that "additional CFAs are needed with more heterogeneous samples in terms of geographic region, race/ethnicity, occupation, age (particularly adolescents and older people), income and religion" (p. 334). Consequently, it is imperative that future research on the QDI examines the degree of factor structure invariance across the major racial/ethnic groups.

The results of Study 1 indicate that the first-order factor structure accounts for $24 \%$ of the variance, and the second-order factor accounts for $20 \%$ of the variance, with the overall factor structure accounting for $44 \%$ of the variance. The findings from Study 1 seem to support the notion that a latent factor, likely to be a general prejudice attitude, accounts for the relationship between the factors identified in the QDI. This finding would account for the high permission has been granted for this version to appear in e-Publications@Marquette. SAGE Publications does not grant permission for this article to be further copied/distributed or hosted elsewhere without the express permission from SAGE Publications. 
intercorrelations found between factors in prior investigations of the QDI (Ponterotto et al., 1995; Utsey \& Ponterotto, 1999) and the theoretical notion that prejudice is a multidimensional construct (Biernat \& Crandell, 1999; Burkard et al, 2001). An examination of the CFA indices from Study 2 suggests that the three-factor structure identified from the development studies (Ponterotto et al., 1995; Utsey \& Ponterotto, 1999) and the higher order four-factor structure and bifactor structure from the present investigation yielded comparable fit statistics. Although the bifactor model demonstrated a slight statistical improvement in chi-square as compared to the higher order model, all three models were statistically comparable and none of these three models can be dismissed at this time. Future research should continue to examine each of these models with other samples that are ethnically and geographically diverse.

Although the factor structure from Studies 1 and 2 provides a solution for all 30 items of the QDI, it is important to note that five of the eight items for the women's equity factor were not salient for the second-order $\mathrm{G}$ factor. Research on racism and sexism suggests that there is a strong correlational relationship between these two constructs; however, conceptually and empirically, there remains some clear distinctions (Fiske \& Taylor, 1991; Sidanius, 1993; Swim, Aikin, Hall, \& Hunter, 1995). Future research should examine and clarify the nature of the relationship between racism and sexism items and factors of the QDI.

The limitations of these investigations are important to note. The factor solution identified in this investigation accounted for $44 \%$ of the total variance. Although these findings are comparable to the prior investigation by Ponterotto et al. (1995), it still suggests that a great deal of error variance is unaccounted for by the factor solution identified in this study. In addition, the samples for both studies consisted of undergraduate students with an aggregate mean age of 19 and an overrepresentation of females in Study 1 and 2 (56\% and $64 \%$, respectively). Future studies about the factor structure of the QDI should examine the replicability of these findings with various age groups and educational levels. In a related issue, the samples were all drawn from the Midwest. As Utsey and Ponterotto (1999) have noted, it is important that researchers examine the generalizability of these permission has been granted for this version to appear in e-Publications@ Marquette. SAGE Publications does not grant permission for this article to be further copied/distributed or hosted elsewhere without the express permission from SAGE Publications. 
findings to other geographical regions. Finally, this is the first investigation of the factor structure of the QDI utilizing a hierarchical factor analysis procedure. It is important to recognize that the findings from Study 1 regarding the factor structure of the QDI may be an artifact of the change in statistical analysis, rather than due to true differences in the sample. Consequently, replication of this study is important.

Based on the results of this investigation, a few recommendations can be made about the use of the QDI and future investigations. First, given that a second-order $\mathrm{G}$ factor has been identified and verified through these two studies, these findings suggest that it is appropriate to report the total score of this QDI general factor in future investigations as a overall measure of prejudice. It is important that future researchers report descriptive data and a coefficient alpha for the full-scale score on the QDI and conduct investigations to examine the utility and validity of the fullscale score. Second, based on past investigations using oblique rotations in factorial analyses, the repeated pattern of intercorrelations, and the current findings from these two studies, it is recommended that future research on the factorial structure of the QDI continue to assess the appropriateness of the hierarchical factor model. The evidence from these current studies suggests that, as an alternative factor analytic model, hierarchical factor analysis may offer breath and depth for our understanding of the QDI factor structure. This model may not be appropriate for samples drawn from other ethnic or age groups, and future investigations should explore the generalizability of these findings across diverse samples. Although the three-factor structure has been a stable and robust finding in research on the QDI (Burkard et al, 2001; Ponterotto et al., 2000), future research should assess the stability, validity, and generalizability of the four-factor structure identified from the current investigations. The continued research along these lines may facilitate our understanding of the multidimensional nature of prejudice.

\section{Note}

- Correspondence regarding this article should be addressed to Alan W. Burkard, Marquette University, School of Education, permission has been granted for this version to appear in e-Publications@Marquette. SAGE Publications does not grant permission for this article to be further copied/distributed or hosted elsewhere without the express permission from SAGE Publications. 
NOT THE PUBLISHED VERSION; this is the author's final, peer-reviewed manuscript. The published version may be accessed by following the link in the citation at the bottom of the page.

P.O. Box 1881, Milwaukee, WI 53201-1881; e-mail:

alan.burkard@marquette.edu.

\section{References}

Bentler, P. M., \& Bonett, D. G. (1980). Significance tests and goodness of fit in the analysis of covariance structures. Psychological Bulletin, 88, 588-606.

Biernat, M., \& Crandall, C. S. (1999). Racial attitudes. In J. P. Robinson, P. R. Shaver, \& L. S. Wrightsman (Eds.), Measures of political attitudes (pp. 297-412). New York: Academic Press.

Bollen, K. A. (1989). Structural equations with latent variables. New York: John Wiley.

Browne, M. W., \& Cudeck, R. (1993). Alternative ways of assessing model fit. In K. A. Bollen \& J. S. Long (Eds.), Testing structural equation models (pp.136-162). Newbury Park, CA: Sage.

Burkard, A. W., Medler, B. R., \& Boticki, M. A. (2001). Prejudice and racism: Challenges and progress in measurement. In J. G. Ponterotto, J. M. Casas, L. A. Suzuki, \& C. M. Alexander (Eds.), Handbook of multicultural counseling (2nd ed., pp. 457-481). Thousand Oaks, CA: Sage.

Carmines, E. G., \& McIver, J. P. (1981). Analyzing models with unobserved variables. In G. W. Bohrnstedt \& E. F. Borgatta (Eds.), Social measurement: Current issues (pp. 65-115). Beverly Hills, CA: Sage.

Dunton, B. C., \& Fazio, R.H. (1997). An individual difference measure of motivation to control prejudiced reactions. Society for Personality and Social Psychology, 23, 316-326.

Fiske, S. T., \& Taylor, S. E. (1991). Social cognition (2nd ed.). New York: McGraw-Hill.

Gaertner, S. L., \& Dovidio, J. F. (1986). The aversive form of racism. In S. L. Gaertner \& J. F. Dovidio (Eds.), Prejudice, discrimination, and racism (pp. 61-89). New York: Academic Press.

Gorsuch, R. L. (1983). Factor analysis (2nd ed.). Hillsdale, NJ: Lawrence Erlbaum.

Greenwald, A. G. (1990). What cognitive representations underlie social attitudes. Bulletin of the Psychonomic Society, 28, 254-260.

James, L. R., Mulaik, S. A., \& Brett, J. M. (1982). Causal analysis: Assumptions, models and data. Beverly Hills, CA: Sage.

Ponterotto, J. G., Burkard, A. W., Rieger, B. P., D'Onofrio, A., DuBuisson, A., Heenehan, M., et al. (1995). Development and initial validation of the Quick Discrimination Index (QDI). Educational and Psychological Measurement, 55, 1016-1031. permission has been granted for this version to appear in e-Publications@ Marquette. SAGE Publications does not grant permission for this article to be further copied/distributed or hosted elsewhere without the express permission from SAGE Publications. 
NOT THE PUBLISHED VERSION; this is the author's final, peer-reviewed manuscript. The published version may be accessed by following the link in the citation at the bottom of the page.

Ponterotto, J. G., Potere, J. C., \& Johansen, S. A. (2000). The Quick Discrimination Index (QDI): Normative data and user guidelines for counseling researchers. Manuscript submitted for publication.

Schmid, J., \& Leiman, J. (1957). The development of hierarchical factor solutions. Psychometrika, 22, 53-61.

Sidanius, J. (1993). The interface between racism and sexism. Journal of Psychology, 127, 311-322.

Stevens, J. (1996). Applied multivariate statistics for the social sciences (3rd ed.). Mahwah, NJ: Lawrence Erlbaum.

Swim, J. K., Aikin, K. J., Hall, W. S., \& Hunter, B. A. (1995). Sexism and racism: Old-fashioned and modern prejudices. Journal of Personality and Social Psychology, 68, 199-214.

Thompson, B. (1990). SECONDOR: A program that computes a second-order principal components analysis and various interpretation aids. Educational and Psychological Measurement, 50, 575-580.

Utsey, S. O., \& Ponterotto, J. G. (1999). Further factorial validity assessment of scores on the Quick Discrimination Index (QDI). Educational and Psychological Measurement, 59, 325-335.

von Hippel, W., Sekaquaptewa, D., \& Vargas, P. (1997). The linguistic intergroup bias as an implicit indicator of prejudice. Journal of Experimental Social Psychology, 33, 490-509.

Yung, Y., Thissen, D., \& McLeod, L. D. (1999). On the relationship between the higher-order factor model and the hierarchical factor model. Psychometrika, 64, 113-128.

Educational and Psychological Measurement, Vol. 62, No. 1 (2002): pg. 64-78. DOI. This article is @ SAGE Publications and permission has been granted for this version to appear in e-Publications@ Marquette. SAGE Publications does not grant permission for this article to be further copied/distributed or hosted elsewhere without the express permission from SAGE Publications. 


\section{Appendix}

Table 1: Factor Intercorrelations, Means, Standard Deviations, and Cronbach's Alphas for the Quick Discrimination Index for the Samples From Study 1 and Study 2

\begin{tabular}{lcccccccc}
\hline \hline & I & II & III & IV & G & $M$ & $S D$ & $\alpha$ \\
\hline Study I $(n=428)$ & & & & & & & & \\
I & - & $.32^{*}$ & $.30^{*}$ & $.50^{*}$ & $.70^{*}$ & 13.67 & 3.66 & .77 \\
II & - & - & $.24^{*}$ & $.39^{*}$ & $.79^{*}$ & 30.42 & 6.14 & .81 \\
III & - & - & - & $.27^{*}$ & $.48^{*}$ & 26.05 & 4.56 & .61 \\
IV & - & - & - & - & $.77^{*}$ & 24.52 & 4.48 & .66 \\
G & - & - & - & - & - & 74.82 & 12.15 & .86 \\
Study 2 $(n=363)$ & & & & & & & & \\
I & - & $.2 *$ & $.36^{*}$ & $.49^{*}$ & $.65^{*}$ & 14.74 & 3.26 & .69 \\
II & - & - & $.27^{*}$ & $.43^{*}$ & $.78^{*}$ & 30.20 & 5.65 & .80 \\
III & - & - & - & $.41^{*}$ & $.56^{*}$ & 27.28 & 4.41 & .55 \\
IV & - & - & - & - & $.81^{*}$ & 26.06 & 4.87 & .70 \\
G & - & - & - & - & - & 77.86 & 11.98 & .84 \\
\hline
\end{tabular}

$* p<.01$

Table 2: Goodness-of-Fit Indicators for the Null Model, Original Three-Factor Solution, Higher Order Four-Factor Solution, and the Bifactor Model $(n=363)$

\begin{tabular}{lrrrrrrrrr}
\hline \hline Model & \multicolumn{1}{c}{$\chi^{2}$} & $d f$ & $p$ & $\chi^{2} / d f$ & NFI & NNFI & PNFI RMSEA \\
\hline Null model (23 items) & $22,378.55$ & 276 & $<.001$ & 81.08 & & & & .47 \\
Oblique three-factor model & 641.90 & 227 & $<.001$ & 2.83 & .97 & .98 & .80 & .07 \\
Null model (30 items) & $29,261.14$ & 465 & $<.001$ & 62.93 & & & & .41 \\
Higher order four-factor & & & & & & & & \\
model & $1,081.42$ & 401 & $<.001$ & 2.70 & .96 & .97 & .83 & .07 \\
Bifactor model & $1,036.38$ & 382 & $<.001$ & 2.71 & .97 & .97 & .79 & .07 \\
\hline
\end{tabular}

Note. NFI = normed fit index; NNFI = nonnormed fit index; PNFI = parsimony adjustment to the NFI; RMSEA = root mean square error of approximation.

Educational and Psychological Measurement, Vol. 62, No. 1 (2002): pg. 64-78. DOI. This article is @ SAGE Publications and permission has been granted for this version to appear in e-Publications@ Marquette. SAGE Publications does not grant permission for this article to be further copied/distributed or hosted elsewhere without the express permission from SAGE Publications. 
NOT THE PUBLISHED VERSION; this is the author's final, peer-reviewed manuscript. The published version may be accessed by following the link in the citation at the bottom of the page.

Figure 1. The bifactor model.

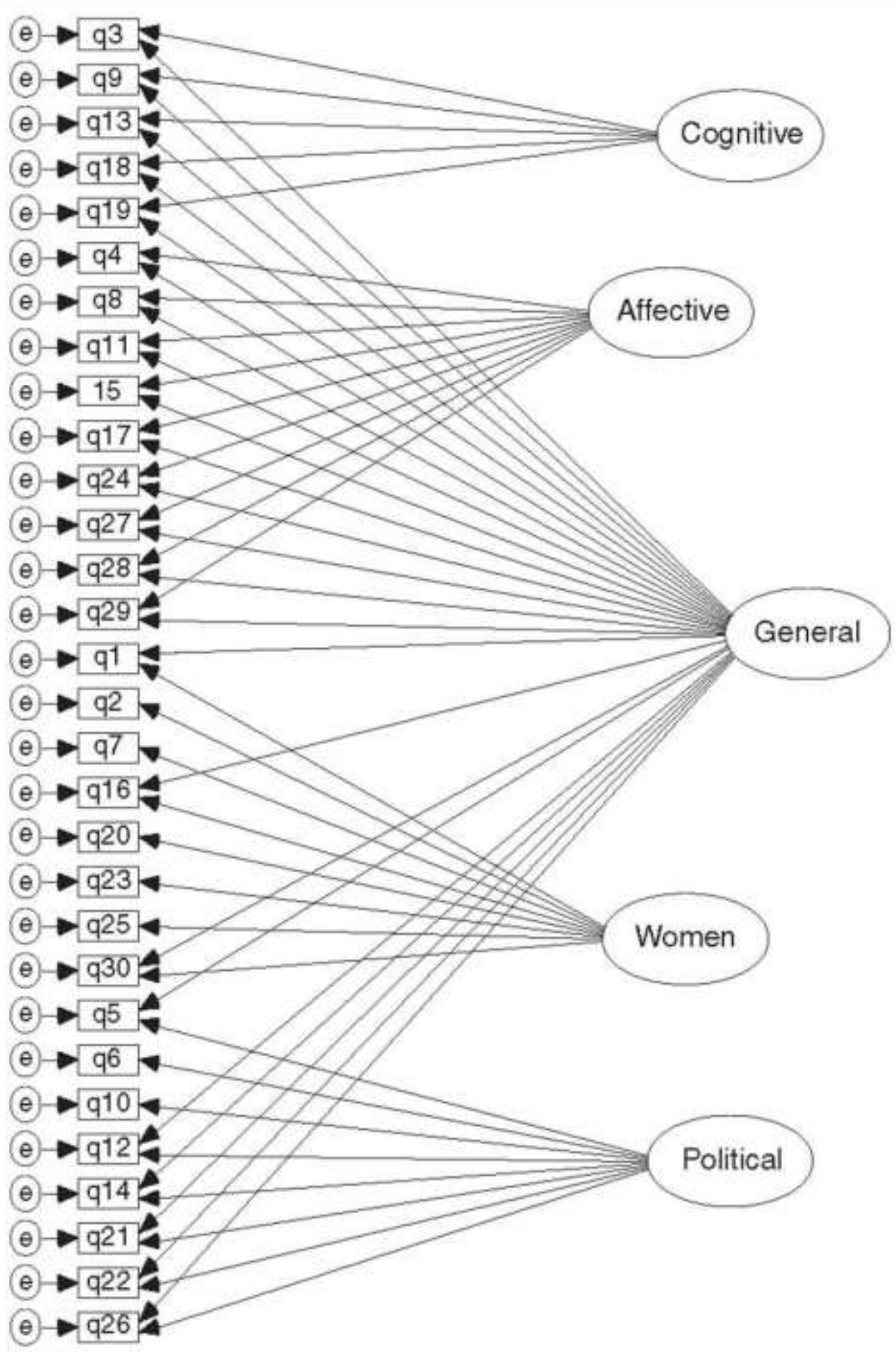

Educational and Psychological Measurement, Vol. 62, No. 1 (2002): pg. 64-78. DOI. This article is (C SAGE Publications and permission has been granted for this version to appear in e-Publications@Marquette. SAGE Publications does not grant permission for this article to be further copied/distributed or hosted elsewhere without the express permission from SAGE Publications. 
NOT THE PUBLISHED VERSION; this is the author's final, peer-reviewed manuscript. The published version may be accessed by following the link in the citation at the bottom of the page.

Figure 2. The higher order model.

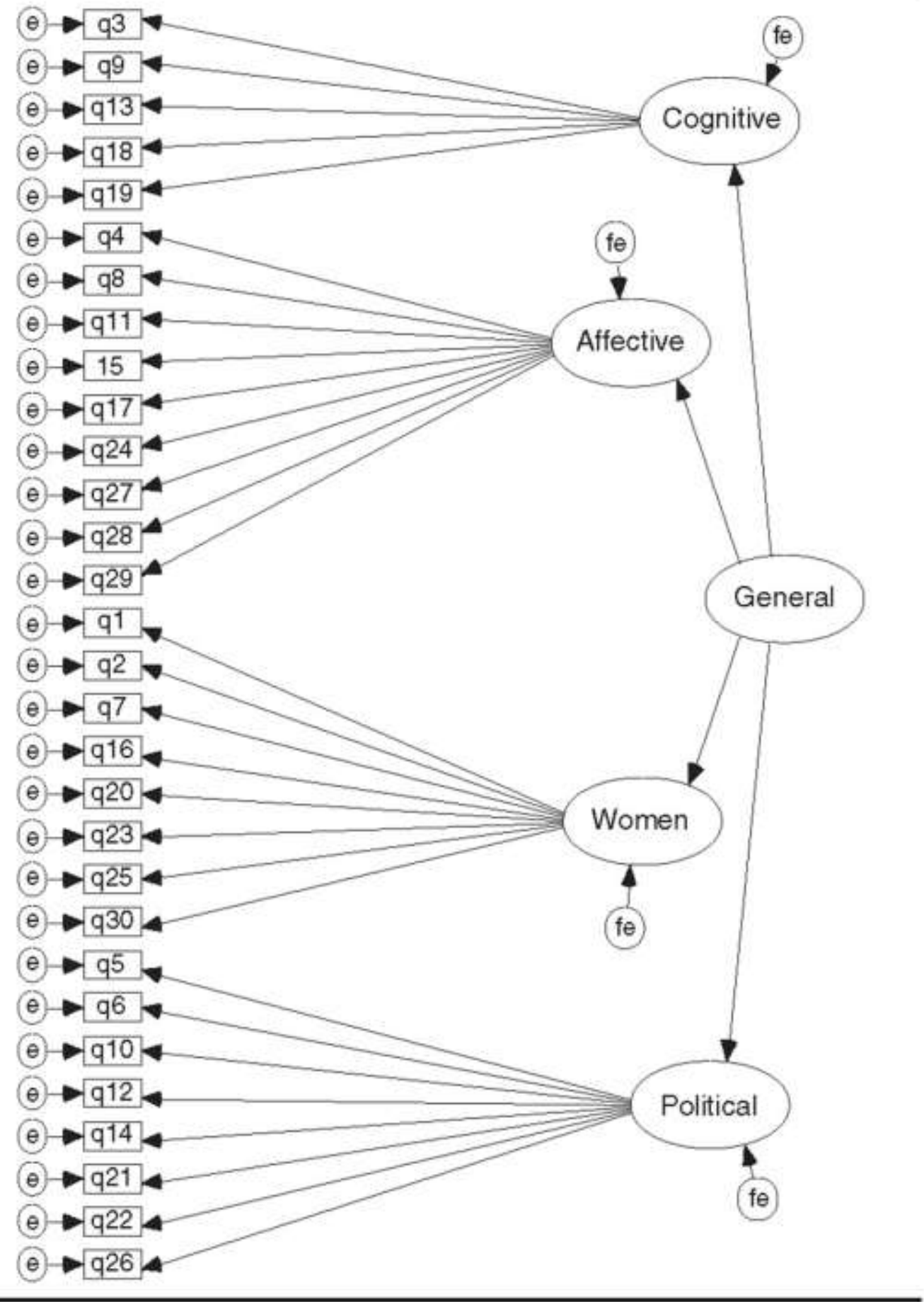

Educational and Psychological Measurement, Vol. 62, No. 1 (2002): pg. 64-78. DOI. This article is (C) SAGE Publications and permission has been granted for this version to appear in e-Publications@Marquette. SAGE Publications does not grant permission for this article to be further copied/distributed or hosted elsewhere without the express permission from SAGE Publications. 
NOT THE PUBLISHED VERSION; this is the author's final, peer-reviewed manuscript. The published version may be accessed by following the link in the citation at the bottom of the page.

\section{Figure 3. The oblique three-factor model}

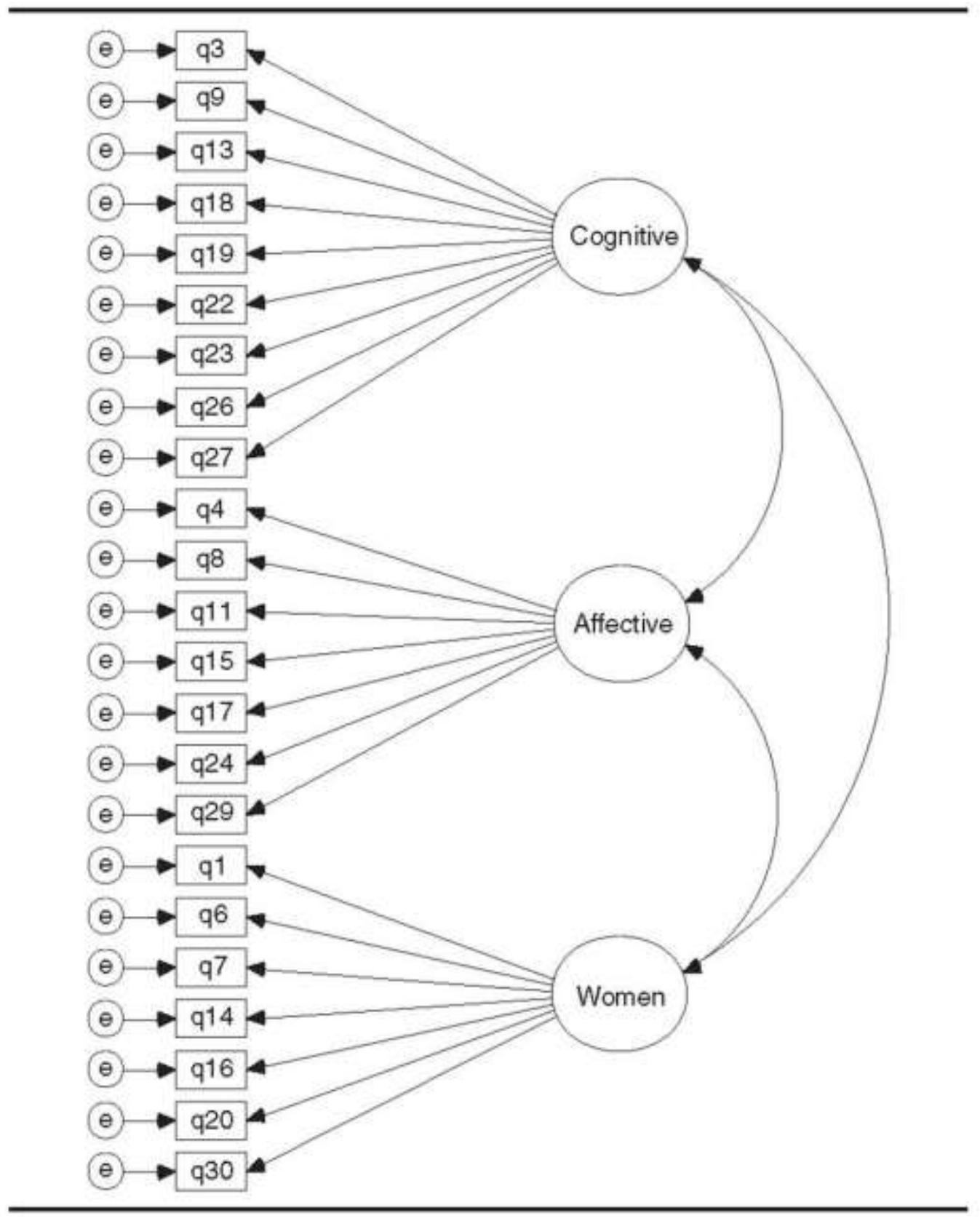

Educational and Psychological Measurement, Vol. 62, No. 1 (2002): pg. 64-78. DOI. This article is (C) SAGE Publications and permission has been granted for this version to appear in e-Publications@ Marquette. SAGE Publications does not grant permission for this article to be further copied/distributed or hosted elsewhere without the express permission from SAGE Publications. 
NOT THE PUBLISHED VERSION; this is the author's final, peer-reviewed manuscript. The published version may be accessed by following the link in the citation at the bottom of the page.

\section{Comparison of the Oblique Rotated and Hierarchical Factor Structures of the Quick Discrimination Index (QDI)}

\begin{tabular}{|c|c|c|c|c|c|c|c|c|}
\hline \multirow[b]{2}{*}{$\begin{array}{l}\text { QDI Item } \\
\text { Number }\end{array}$} & \multicolumn{3}{|c|}{$\begin{array}{l}\text { Oblique Three-Factor } \\
\qquad(n=220)\end{array}$} & \multicolumn{5}{|c|}{$\begin{array}{l}\text { Orthogonal Hierarchical } \\
\text { Solution }(n=428)\end{array}$} \\
\hline & P.I & P.II & P.III & I & II & III & IV & G \\
\hline 1 & & & -.46 & & & .51 & & .28 \\
\hline $2^{\mathrm{a}}$ & & & & & & .41 & & \\
\hline 3 & .50 & & & -.40 & & & & .42 \\
\hline 4 & & -.76 & & & .51 & & & .45 \\
\hline $5^{a}$ & & & & & & & -.34 & .34 \\
\hline 6 & & & -.76 & & & 31 & -.54 & .41 \\
\hline 7 & & & -.68 & & & .66 & & \\
\hline 8 & & -.73 & & & .36 & -.28 & & .27 \\
\hline 9 & .40 & & .38 & -.37 & & & & .52 \\
\hline $10^{\mathrm{a}}$ & & & & & & & .31 & \\
\hline 11 & & -.83 & & & .56 & & & .55 \\
\hline $12^{2}$ & .53 & -.44 & -.52 & & & & -.47 & .61 \\
\hline 13 & .80 & & & -.47 & & & & .55 \\
\hline 14 & & & -.58 & & & & -.45 & .44 \\
\hline 15 & & -.58 & & & .25 & & & .30 \\
\hline 16 & & & -.70 & & & .62 & & 36 \\
\hline 17 & & -.51 & & & .36 & & & .57 \\
\hline 18 & .74 & & .35 & -.49 & & & & .63 \\
\hline 19 & .78 & & & -.44 & & & & .66 \\
\hline 20 & & & -.47 & & & .40 & -.32 & \\
\hline $21^{2}$ & 60 & & -.51 & & & & -.48 & .50 \\
\hline 22 & .66 & & & & & -.29 & -.30 & .50 \\
\hline 23 & .41 & & & & & .29 & & \\
\hline 24 & & -60 & -41 & & .45 & & & .58 \\
\hline $25^{\mathrm{a}}$ & & & & & & .33 & & \\
\hline 26 & .46 & & & & .27 & & -.35 & .61 \\
\hline 27 & .55 & & & & .27 & & & .54 \\
\hline $28^{a}$ & .45 & -.70 & & & .48 & & & .61 \\
\hline 29 & & -.74 & & & .45 & & & .47 \\
\hline 30 & & & -.64 & & & .48 & -.33 & .30 \\
\hline
\end{tabular}

Note. Ponterotto et al. (1995) set a cutoff criterion of .40 for the oblique three-factor structure, and only structure coefficients greater than twice the critical value of the correlation coefficient ( $p=.01$, two-tailed test) are shown for either solution. The structure coefficients salient to the factor are italicized.

a. Items eliminated by Ponterotto et al. (1995) for 23-item oblique three-factor structure. 